\title{
An overview of coastal development in a Young Mountain Belt-Taiwan
}

\author{
P.M. Liew ${ }^{\mathrm{a}, *}$, M.L. Hsieh ${ }^{\mathrm{a}}$, B.H. Shyu ${ }^{\mathrm{b}}$ \\ ${ }^{a}$ Department of Geosciences, National Taiwan University, 1, Sec 4 Roosevelt Road, Taipei 106, Taiwan, ROC \\ ${ }^{\mathrm{b}}$ Division of Geological and Planetary Sciences, Caltech, USA
}

\begin{abstract}
The coastal morphology of Taiwan exhibits characteristics of collisional tectonism superimposed upon global sea level changes. The island's eastern coast is situated on the accreted Luzon arc alongside the NE-SW trending plate boundary. To the west, the Central Range, Hsueshan Range and Western Foothills are the fold and thrust belts of the island. They are the raised continental shelf and slope sediments or meta-sediments of the Chinese continental margin. The northern and southern coasts of the island are in the two tips of these belts. The western coastal area is mostly in the foreland of the orogen.

Situated on the accreted arc proximal to the collision zone, the middle and southern portions of the eastern coast have high uplift rates of up to $9-10 \mathrm{~mm} / \mathrm{yr}$. Holocene transgression deposits reach $50 \mathrm{~m}$ amsl or more. There are commonly 3-4 flights of Holocene terraces. Thrusts and warping are recognizable along the northern and southern coasts because they trend perpendicular to the main fold and thrust belts of the island. The Holocene uplift rates are typically about $0-5 \mathrm{~mm} / \mathrm{yr}$. Higher rates occur in the upthrown limbs of the thrusts or areas proximal to up-warping axes.

Sitting on the foreland basin, the development of the western coast is related to the westwardly propagation of fold and thrust belts which in turn are influenced by the lithological rigidity of the underlying basement. Coastal areas underlain by two Mesozoic basement highs are relatively stable or have low subsiding rates (about $2-3 \mathrm{~mm} / \mathrm{yr}$ ). Between these basement highs lie an area occupied by the west front of the fold and thrust belts, which has an uplift rate similar to the northern and southern coasts. To the south of the basement highs, the coastal plains probably conceal newly developed folds or faults where SW trending, paleo-incised valleys and domes of Late Pleistocene and Holocene age exist beneath the coastal plains' surfaces as indicated by several tens of drilling cores from the plains. This suggests an incipient stage of fold and thrust belt development. The southwestern-most coastal plains are believed to be a piggy-back basin of the fold and thrust belts, showing a higher subsidence rate $(6-8 \mathrm{~mm} / \mathrm{yr})$ than other parts of the western coast.
\end{abstract}

(C) 2003 Elsevier Ltd and INQUA. All rights reserved.

\section{Introduction}

Taiwan is situated in the northeast trending collision zone of the Eurasian plate and Philippine Sea plate. The history of the young mountain belt has been well documented in literature (Teng, 1990; Huang et al., 1997). Crustal movement is active today, as witnessed by the intense earthquakes and high uplift rates of this island. The eastern coast is located in the frontal zone of a collision boundary, where the accreted arc and forearc sediments crop out. The accretion due to arc-continent collision has continued since Late Miocene time during the rise of the Asian continental shelf, to build this highrelief island. Westward of the Coastal Range, across the

*Corresponding author.

E-mail address: liewpm@ccms.ntu.edu.tw (P.M. Liew). longitudinal valley, is the backbone of the island, the Central Range and the Hsueshan Range (Fig. 1). The former is made up of pre-Tertiary metamorphic rock and the latter is composed of Paleogene slate and metasandstone. Westward of these are the Western Foothills and Western Coastal Plains. The Western Foothills are composed of folded Tertiary sedimentary rocks previously deposited on the Asian continental shelf. Morphologically, the backbone area and the Western Foothills represent the fold and thrust belts, the southern and northern tips of which are the island's southern and northern coasts. The Western Coastal Plains are in the foreland basin of this island's orogen (Fig. 1).

In recent years, increasing data have become available to allow the deciphering of differences among coasts of various tectonic units. According to recent crustal 


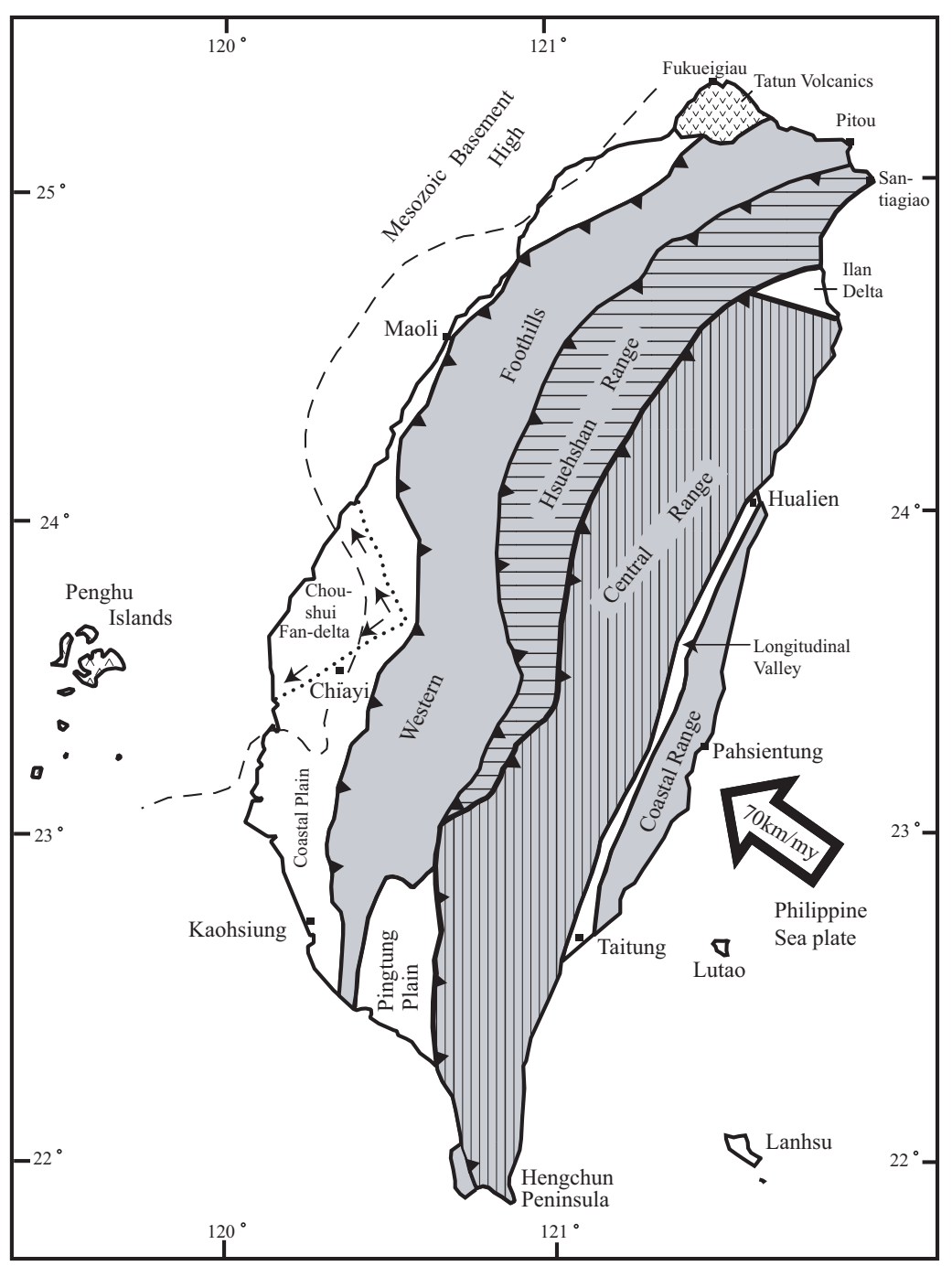

Fig. 1. Tectonic units of Taiwan and the coastal areas as discussed in the text.

movements, Holocene transgression sediments can be raised to as high as more than $50 \mathrm{~m}$ amsl, or can subside to $100 \mathrm{~m}$ below sea level. It is worth studying how the coastal development responds to the tectonic regime by the morphological contrasts. In this article, we describe differential uplifts and subsidence based on the data revealed by the morphology or thickness of Holocene sediments from the coasts of Taiwan so as to understand their development history.

\section{Active uplift in the eastern coast}

The eastern coast from Hualien to Taitung is characterized by its beautiful terraces and sea caves, indicating active uplift along the NE-SW collision zone of the Eurasian and Philippine Sea plates. The basement of the coastal zone is composed of folded PlioPleistocene turbidite sequences of fore-arc and intra-arc basins and the volcaniclastic rocks of the arc. Marine terraces are better developed where sedimentary rock is the basement, usually with lower altitudes in the north and higher in the middle and south due to differential uplift rates along the coast. High uplift rates of the middle and southern parts have been documented (Liew et al., 1990, 1993; Wang and Burnett, 1990). More than 120 radiometric dates from raised reef fragments, or material contained in the raised marine sediments, confirm this rapid uplift (Hsieh et al., 2003). Most of the well-preserved flights along the coast were formed during the Holocene. Generally, the higher one or two flights are wider, better extended and are commonly followed in their coastal side by several small, narrow steps. According to Chen and Liu (1996), Holocene transgression in the Penghu Islands offshore from western Taiwan culminated at $5 \mathrm{ka}$. Small fluctuations of sea level after $5 \mathrm{ka}$ existed, with at least a small rise at about $2 \mathrm{ka}$ (Liew and Hsieh, 1999). Under such high 
uplift rates, the formation of terraces and their morphology of the eastern coast may differ from ordinary conditions familiar on more stable terrains. The origins of the multiple steps during Holocene time may be related to the following conditions: (1) sea-level fluctuations due to millennial-time scale climatic changes superimposed on Holocene transgression, culmination, and later retreat (due to continuous landuplift); (2) consequent sediment supply and the effectiveness of wave erosion during millennial-time scale climatic change, superimposed on sea-level changes; and (3) paleoseismicity superimposed on sea-level changes. Dating each flight of a terrace sequence is difficult if suitable material, crucial for understanding its origin, is scant. Recently, one coseismic fan was inferred based on the consistent chronology of different facies of a profile cropping out within the northern portion. This indicates that coseismic movement occurred near the coastal zone.

A well preserved terrace in the middle part of the coast south of Pahsientung with its outer edge at about 40-50 mamsl, is dated at about 5-6 ka (Hsieh et al., 2003) based on samples from the outer edge where nearshore sediments are covered by thin fluvial deposits. The inner edge of this flight merges into a foothill fan ranging up to $85 \mathrm{mamsl}$. Further south, the wellpreserved highest flight ranges up to $70-80 \mathrm{~m}$ with a marginal scarp of about $20 \mathrm{~m}$ high, down to the secondhighest terrace flight. These two wide terraces are usually followed by several narrow steps coastward. There, including those small steps, the largest number (8) of steps of the terrace sequence is recognized (Yamaguchi, 1989). The profile of the highest terrace shows thick near-shore sediments grading upward to beach sediments, although they are often covered with fluvial deposits, colluvium or vegetation. Profiles of the next lower flight commonly show nearshore sediments overlapped with fluvial deposits indicating missing beach sediments between them. Judging from the sediments of terrace profiles, the formation of the highest two terrace sequence is probably related to the time interval when the rate of Holocene sea level rise kept pace with rate of land-uplift. After the relative culmination of transgression, relative sea level began to retreat due to continuous uplift of the land. The retreat resulted in erosion of the Holocene transgression sediments and sometimes left thin beach deposits over them. Subsequent younger steps thus may have formed from regression when small fluctuations of sea level overprinted the uplifting land, or from other reasons such as erosion by storm waves. These small steps were often covered by fluvial deposits after emergence. The altitude and age of the highest terrace differ from north to south due to different uplift rates along the coast, which in turn resulted from the oblique collision. Recently, the late glacial record of sea level changes was clarified (Hanebuth et al., 2002), providing possible intervals when the rate of sea level rise approximated that of land uplift of eastern Taiwan. This part of the eastern coast is the sector where the contemporary uplift rate is the highest, as shown by recent geodetic data (Liu and $\mathrm{Yu}, 1990)$. At about this point the Luzon arc recently collided with the eastern Asia continental shelf (Huang et al., 1997). It is plausible that the highest Holocene marine sediments in the inner edge of this highly uplifting part (up to $10 \mathrm{~mm} / \mathrm{yr}$ or even more, see Hsieh et al., 2003), were not necessarily deposited during the age of general culmination of Holocene transgression such as 5-6 ka, but rather could be older. Radiometric dating supports this inference (Hsieh, 1990).

Differential uplift rates along the eastern coast produced the highest terrace in the middle and southern parts. Terraces are better developed and preserved in the middle part of the coast. They are not so well preserved in the southernmost part, probably because of the very high uplift rates mentioned by Hsieh et al. (2003). The altitude distribution of the terraces generally coincides with the trends of the geodetic data (Liu and $\mathrm{Yu}, 1990$ ). At higher altitudes, terraces are hardly preserved, due to rapid erosion on this island, but the existing summit levels may be remnants of Pleistocene terraces.

In the northern part of the eastern coast, terraces are lower and narrower, although similar to those in the southern part in morphology with one wider flight, followed by 2 or 3 much narrower and lower steps. The well-preserved highest flight is about $20-25 \mathrm{~m}$, in its inner edge near Hualien. In this portion, the terrace is not well developed mostly due to the erosional resistance of the volcaniclastic basement. Sea caves or notches are well developed locally, for example, north of Pahsientung. Notches or narrow abrasion platforms there show four episodic stages of sea level stands, but whether they are due to millennial climatic changes or episodic uplifts from paleoseismicity is unclear. Generally, less rapid uplift rates of the northern sector are accepted (Liew et al., 1990).

North of Hualien, the terrace is not found and some parts of the coast are difficult to access due to high cliffs formed by metamorphic rock. The Ilan Delta (Fig. 1) at the northeastern coast is a western extension of the Okinawa Trough and is characterized by a remarkable subsiding rate of $6-10 \mathrm{~mm} / \mathrm{yr}$ (Lai and Hsieh, 2003).

\section{Southern coast}

The southern and northern coasts, the two tips of the backbone of this island, belong to the NE-SW trending fold and thrust belts. Values of uplift or subsidence vary according to the proximity of the area to local fold axes or faults. The Holocene terrace is commonly $10-15 \mathrm{~m}$ high. The uplift rates of these coasts are usually 
$2-3 \mathrm{~mm} / \mathrm{yr}$ on average, but may range from 0 to $5 \mathrm{~mm} / \mathrm{yr}$ (Lin, 1969; Taira, 1975; Lou, 1989; Chen, 1993).

At present, the southern coast in the Hengchun Peninsula is characterized by a fringing reef which exhibits remarkable thrusts and warpings. The Holocene terrace is variably exposed along the coast as a fringe below the higher Pleistocene terraces. The altitudes of the inner edges of the Holocene terrace from east to west ranges from about $10 \mathrm{mamsl}$ in the eastern part, to about $36 \mathrm{~m}$ amsl in the middle part at an upthrown side of an active thrust (Liew and Lin, 1987). The profile near the highest altitude area $(36 \mathrm{~m})$ is represented by beach deposits composing of sand and coral fragments in which the highest coral fragments exposed are dated at about $7 \mathrm{ka}$ (Lin, 1989), older than the culmination age of the Holocene transgression. Further west, across the NW trending fault system where Hengchun valley is located, the Holocene terrace fringes a landward-facing, Late Pleistocene terrace covered by lateritic soil. The altitudes of the Holocene terrace are again higher in the west, exhibiting the landward-tilting morphology inherited from the Pleistocene platform. Indistinct steps developed on the Holocene reef terrace of this part of coast where the uplift rate is higher than $5 \mathrm{~mm} / \mathrm{yr}$. It is most likely that in addition to the thrust in the middle part of Hengchun Peninsula there is another active westverging thrust beneath the terraces extending offshore since the Late Pleistocene.

In addition to major west-verging thrusts, small scale warping is not uncommon, resulting in differential altitudes of the Holocene terraces such as in the eastern limb of the southern coast (Liew and Lin, 1987). In this region of active compression, the ages of raised Holocene terraces range usually between 8 and $4 \mathrm{ka}$, and with various altitudes (Chen, 1993), exhibiting characteristics of the young fold and thrust belts.

Terraces are not visible in the part of southern coasts immediately north of the Hengchun Peninsula. The landscape is well covered by Pleistocene lateritic soil, indicating low rates of both uplift and erosion. How this region is related to local structure needs further study. Further north, along the coasts north of Kaohsiung (southwestern coast of this island) or Taitung (southeastern coastal areas), clear uplift appears again.

\section{Northern coast}

The northern coast of this island is characterized by several flights of terraces including ones of Late Pleistocene age. The basement of the coastal area is of folded Tertiary sedimentary rocks in the eastern part, but middle to Late Pleistocene volcanic rocks in the western part (Fig. 1). The altitude of the Holocene terrace commonly range from 10 to $15 \mathrm{~m}$. Above that, at least two to three Pleistocene terraces are covered by lateritic soil. They are especially clear in the westward volcanic-volcaniclastic area (Tan, 1933; Lin, 1959; Lou, 1989) where the youngest record of volcanism is $0.2 \mathrm{Ma}$ (Song et al., 2000). Judging from the height of the Holocene terrace (Lin, 1969; Taira, 1975; Peng et al., 1977; Hsu, 1988; Lou, 1989), the uplift rates range from about 2 to $5 \mathrm{~mm} / \mathrm{yr}$ in the western portion of the coast where volcanic activity is responsible for the higher rate. In contrast to the southern coast where the terrace flights are strongly influenced by active faults or warping, the Pleistocene terraces of the northern coast are more continuous and easily recognized. This indicates that compression-related thrusts or warping from the Philippine Sea plate are less active in northern coastal areas. In the western portion of the coast, the Holocene terrace is at or slightly lower than $15 \mathrm{~m}$ amsl near Taoshih (Fig. 2) (Hsu, 1988; Lou, 1989), and in the vicinity are higher surfaces at 40-60, 100-150 and 200 $240 \mathrm{~m}$ amsl. Surfaces with good extension parallel to the coast are marine terraces, although some local surfaces may be formed by lava flows (Lin, 1959). From the northernmost point at Fukueigiao landward (Fig. 2), the surfaces are at altitudes of 15, 60, 100-140, 220 and $310 \mathrm{~m}$. Tan (1933) mentioned the existence of even higher marine abrasional surfaces at altitudes of about $500 \mathrm{~m}$. The lower two terraces of 15 and $50-60 \mathrm{~m}$ in this area have been confirmed as marine terraces by Lou (1989). Concerning the altitudes of terrace sequences in

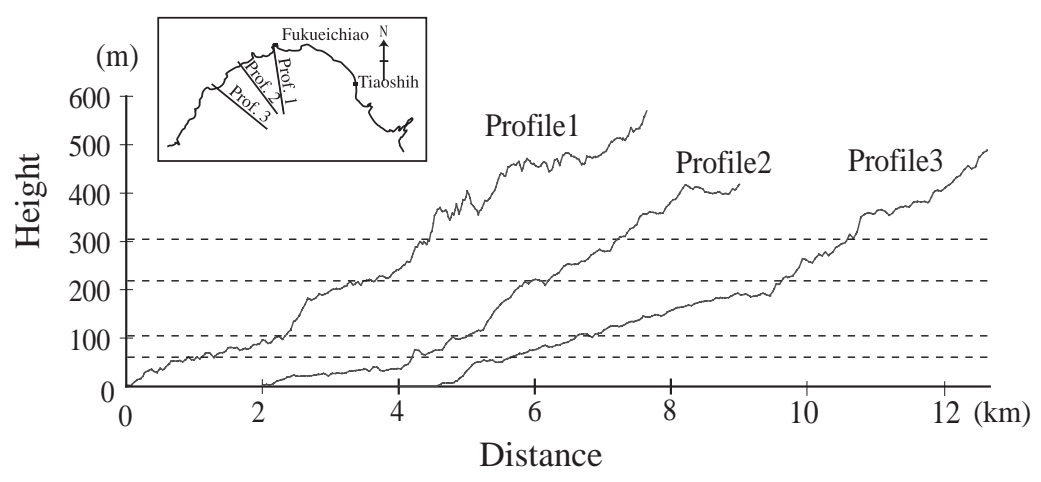

Fig. 2. Topographic profiles of the northern coast near Fukueigiao. 
this part, they appear meaningful if referred to the sea level curve suggested by Lambeck and Chappell (2002), and assuming a constant uplift rate of $2.5 \mathrm{~mm} / \mathrm{yr}$ as proposed by Bull (1984). The ages of these surfaces would then be related closely to high sea level intervals of $6 \mathrm{ka}$, sea level $+2 \mathrm{~m}(15 \mathrm{~m}) ; 45 \mathrm{ka}$, sea level $-53 \mathrm{~m}$ (50-60 m); $60 \mathrm{ka}$, sea level $-48 \mathrm{~m}(102 \mathrm{~m}) ; 70 \mathrm{ka}$, sea level $-37 \mathrm{~m} \quad(138 \mathrm{~m}) ; 84-90 \mathrm{ka}$, sea level -20 to $-25 \mathrm{~m}$ $(200 \mathrm{~m}) ; 100 \mathrm{ka}$, sea level -20 to $-25 \mathrm{~m},(225 \mathrm{~m})$; and $119-128 \mathrm{ka}$, sea level $+2 \mathrm{~m}(310 \mathrm{~m})$. If this is true, it suggests that this region's major surfaces are marine terraces of Late Pleistocene age and that the coast is rising at almost a constant rate. Away from the Tatun volcanic terrain eastward, the altitude of the Holocene terrace decreases slightly from nearly $15 \mathrm{~m}$ down to $10 \mathrm{~m}$, indicating a lower uplift rate. Older terraces with altitudes of 40-60 and $70-130 \mathrm{~m}$ are visible, lower in altitude than the corresponding flights on western portion of the northern coast. Further east from Pitou to Santiaogiao (Fig. 1), the altitude of the Holocene terrace varies from 8 to $15 \mathrm{~m}$. Two older terraces with indefinite altitudes are recognized, with the higher one at about $105 \mathrm{~m}$ amsl (Hsu, 1988), which is again lower than the altitude of the possible corresponding terrace in the western coastal portion. The variable altitudes of the corresponding terraces indicate that the structural control is a factor. Nevertheless, they are not as conspicuous as those on the southern coast.

Offshore of the eastern portion of northern coast is the submarine Taiwan Sinzi (Sun, 1982) which is a submerged fold and thrust belt extended north from northern Taiwan. Studies (Teng et al., 2000) indicate that the recent stress fields of northern Taiwan have changed from compression to extension, as recent geodetic data indicate (Yu et al., 1997). However, along the coast, the Holocene terrace can still be as high as $10 \mathrm{~m}$ or more (Hsu, 1988), suggesting uplift's at least during most of Holocene (Taira, 1975). Changing uplift rates in part of the coast during Holocene time have been reported (Peng et al., 1977). Probably the rates decreased greatly in the very recent past, since bench mark studies show subsidence between 1914 and 1979 (Chen, 1984).

\section{Western coast}

Most of the western coastal plains are considered to be in the foreland basin of the orogen forming this island. In the past several years, hundreds of cores have been recovered from the western coastal plains by the Central Geological Survey for groundwater studies, to further understand subsurface sedimentary framework. According to sedimentological and paleontological studies of cores from the central part-Choushui fan delta (Fig. 1), the marine incursion of the last interglacial is recognized as between 100 and $150 \mathrm{~m}$ below surface level (Liew and Lai, 1996). This incursion is widely distributed eastward all the way to the foothills. Holocene sediments of a later marine transgression are represented by the upper $50 \mathrm{~m}$ of sediments, but the transgression sediments are distributed less extensively landward compared with those of the last interglacial transgression. An incursion during an interstadial of the last glacial is the smallest, and is as found only near the coast. This part, being underlain by the Mesozoic basement high, is the most stable area from a tectonic point of view, possessing a very low subsiding rate only of $0.7-1.1 \mathrm{~mm} / \mathrm{yr}$ since the last interglacial, but $2-3 \mathrm{~mm}$ since latest Pleistocene (Lai and Hsieh, 2003).

Apart from the basement high are areas of fold and thrust belts that in configuration approximate the coast. They are characterized by coastal uplift rates similar to those in the fold and thrust belts at the northern and southern coasts. For example, the Holocene terrace in the Miaoli area rises to about $10-15 \mathrm{~m}$ amsl (Lin, 1963).

To the south of the basement high in the southwestern coast, numerous cores from the coastal plain show that there are many subparallel, SW-trending, paleo-incised valley and ridges of Late Pleistocene age under the plains (Huang, 2001; Chen, 1993; Sung, 2001). The Holocene sediments are as thick as $100 \mathrm{~m}$ in the paleoincised valleys, but are much thinner in the neighboring up-warping areas, such as at the coastal zones of Kaohsiung (Sung, 2001) and Chiayi (Huang, 2001). Thus, the coastal zone of the southwest is characterized by alternating uplift and subsidence indicating the development of incipient fold and thrust belts.

The coastal plain of the most southwestern area, the Pingtung Plain, is believed to be a piggy-back basin of the fold and thrust belts with Holocene sediments ranging to $120 \mathrm{~m}$ in thickness as shown in the Chifon core of the plain (Fig. 3) (Shyu, 1999). The subsidence rates here are higher than in any other part of the western coastal area, approximately $6-8 \mathrm{~mm} / \mathrm{yr}$ since latest Pleistocene (Lai and Hsieh, 2003). Sedimentary records can potentially detail the episodic sea level changes during deglaciation.

The coastal plains of western Taiwan, although flat in morphology, are affected by different developmental processes. Stable areas are characterized by relatively low subsidence rates whereas various subsiding or uplifting rates exist where the incipient fold and thrust belts develops.

\section{Summary}

Under active arc-continent collision, the tectonic morphology of this island is remarkable. On the eastern coast, the collision results in high rates of uplift. At the 


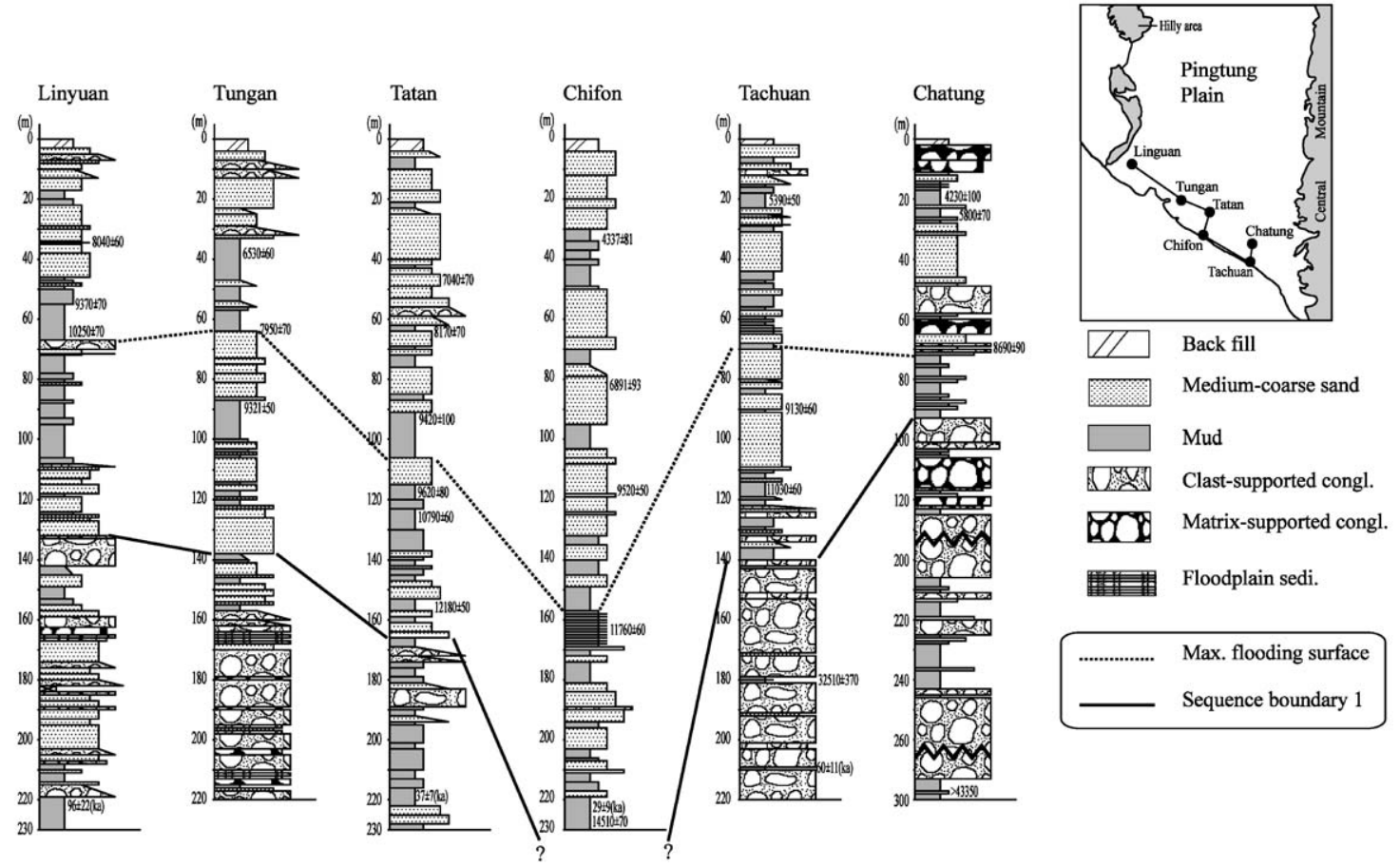

Fig. 3. Subsurface cores from the Pingtung Plain, southwestern Taiwan, which show that the Holocene sediments are up to $120 \mathrm{~m}$ thick or more (Chifon core) in the subsiding part of the plain.

NW trending collision zone, compression from north to south is differential, with higher uplift rates southward. The Holocene terraces are multi-stepped, rising as high as $50 \mathrm{mamsl}$ or more. In the northern and southern coasts, i.e. at the two tips of the fold and thrust belts, the general altitude of the Holocene terrace is $10-15 \mathrm{~m}$ amsl with clear changes in altitudes according to local faults or warping axes. The existence of thrusting or warping is more remarkable on the southern than on the northern coast. Most of the western coastal areas are in the foreland basin of this island, but they are undergoing differential uplift or subsidence due to the recent developments of the incipient fold and thrust belts, except for the stable area underlain by a rigid basement high.

The average uplift rates along the coasts of this island since Late Quaternary are as follows:

1. Eastern coast - the accreted arc is dominated by differential uplift with the highest rate at least $9-10 \mathrm{~mm} / \mathrm{yr}$.

2. Southern coast - fold and thrust belts of this young mountain belt. The occurrence of thrusts and warpings are remarkable, with uplift rates usually at $0-5 \mathrm{~mm} / \mathrm{yr}$, but higher on the upthrown sides of a thrust or at warping axes.

3. Northern coast - fold and thrust belts of this young mountain belt with Pleistocene volcanoes in the western part. The uplifting rates are commonly an average of $0-4 \mathrm{~mm} / \mathrm{yr}$ but are usually higher westward in the volcanic terrain. Eastern portions of the northern coast may have experienced a decrease in uplift rate in the recent past.

4. Western coast - foreland of this young mountain belt, being partly occupied by incipient folds and thrusts. The stable portion is marked by very low subsiding rates $(0.7-1.1 \mathrm{~mm} / \mathrm{yr})$ since the last interglacial but $2-3 \mathrm{~mm} / \mathrm{yr}$ since the last glacial maximum. In the incipient folds and thrusts portion, subsidence or uplift depends on locations with respect to fold axes or faults. Subsidence rates are up to $4 \mathrm{~mm} / \mathrm{yr}$, and uplift rates may be up to $4-5 \mathrm{~mm} / \mathrm{yr}$ since the latest Pleistocene.

5. Southwestern-most coast - a piggy back basin of fold and thrust belts, with subsidence rates commonly up to $6-8 \mathrm{~mm} / \mathrm{yr}$ since the latest Pleistocene.

Neotectonism dominates the morphology of this island including the entire coastal area. Coasts of different tectonic units were developed closely related to their tectonic intensity and style. The coastal zone demonstrates the development patterns resulted from structural elements and shows differential uplift or subsidence. The coast of Taiwan is an outstanding example for the general trends of coastal evolution in active young mountain belts. 


\section{Acknowledgements}

This study was provided with grants from the National Science Council. We are grateful to Dr. Yoko Ota of the Yokohama University for her encouragement at the beginning of this study. Thanks are also due to Dr. Pirazzoli for his in depth discussions during the study. We are also in debt to Mr. Lai Cheng-Kuo who took part in the field survey in the first year of the study. The reviewers' instructive suggestions on this paper are highly appreciated.

\section{References}

Bull, W.B., 1984. Correlation of flights of global marine terraces. In: Morisawa, M., Hack, J.T. (Eds.), Tectonic Geomorphology. Allen \& Unwin, London, Boston, pp. 129-152.

Chen, H.F., 1984. Crustal uplift and subsidence in Taiwan: an account based upon retriangulation results. Vol. 3, Central Geological Survey Special Publication, Taiwan, pp. 141-159 (in Chinese).

Chen, Y.G., 1993. Sea level change and neotectonics in southern part of Taiwan Region since Late Pleistocene. Ph. D. Dissertation, Department of Geosciences, National Taiwan University, Taipei, 158p.

Chen, Y.G., Liu, T.K., 1996. Sea level changes in the last several thousand years, Penghu Islands, Taiwan Strait. Quaternary Research 45, 254-262.

Hanebuth, T., Stattegger, K., Grootes, P.M., 2002. Rapid flooding of the Sunda Shelf: a late-glacial sea-level record. Science 288, 1033-1040.

Hsieh, M.L., 1990. Study of the Late Quaternary deposits, marine terraces and the neotectonism of coastal areas between Hualien and Taitung, eastern Taiwan. Master's Thesis, National Taiwan University, Taipei, 168p.

Hsieh, M.L., Liew, P.M., Hsu, M.Y., 2003. Holocene tectonic uplift on the Hua-tung coast, eastern Taiwan. Quaternary International, doi:10.1016/S1040-6182(03)00096-X.

Hsu, M.Y., 1988. A geomorphological study of marine terraces in Taiwan. Ph. D. Dissertation, Department of Geology, Chinese Cultural University, Taipei, 178p.

Huang, Y.T., 2001. Upper Quaternary sedimentary environments and sequence stratigraphy of the Tsengwen-hsi River Basin, Chianan Plains; a preliminary study. Master's Thesis, National Taiwan University, Taipei, p. 187 (in Chinese).

Huang, C.Y., Wu, W.Y., Chang, C.P., Tsao, S., Yuan, P.B., Lin, C.W., Xia, K.Y., 1997. Tectonic evolution of accretionary prism in the arc-continental collision terrain of Taiwan. Tectonophysics $281,31-51$

Lai, T.H., Hsieh, M.L., 2003. Late Quaternary vertical rock-movement rates of the coastal plains of Taiwan. Programs with abstracts, 2003 annual meeting, Geological Society Society of China, Taipei, p. 119.

Lambeck, K., Chappell, J., 2002. Sea level change through the last glacial cycle. Science 292 (5517), 679.

Liew, P.M., Hsieh, M.L., 1999. Late Holocene (2 ka) sea level, river discharge and climate interrelationship in Taiwan region. Journal Asian Earth Sciences 18, 499-505.
Liew, P.M., Lai, T.H., 1996. Paleoclimate and paleoenvironmental changes of southern Choushui-hsi Plains since the last 200 ka-palynological study. Symposium on the groundwater and hydrological geology of the Choushui-hsi Plains, pp. 67-78 (in Chinese).

Liew, P.M., Lin, C.F., 1987. Holocene tectonic activity of the Hengchun Peninsula as evidenced by the deformation of marine terraces. Memoir, Geological Society of China 9, 241-259.

Liew, P.M., Hsieh, M.L., Lai, C.K., 1990. Tectonic significance of Holocene marine terraces in the coastal range, eastern Taiwan. Tectonophysics 183, 121-127.

Liew, P.M., Pirazzoli, P.A., Hsieh, M.L., Arnold, M., Barusseau, J.P., Fontugne, M., Giresse, P., 1993. Holocene tectonic uplift deduced from elevated shorelines, eastern Coastal Range of Taiwan. Tectonophysics 222, 55-68.

Lin, C.C., 1959. Geomorphology of Taiwan. Taiwan, Wen Sieng, 424p (in Chinese).

Lin, C.C., 1963. The Lungkang Formation, lower marine terrace deposits near Miaoli. Petroleum Geology of Taiwan 2, 87-105.

Lin, C.C., 1969. Holocene geology of Taiwan. Acta Geologica Taiwanica 13, 83-126.

Lin, C.F., 1989. Uranium series dating of Holocene raised corals from Hengchun Peninsula and eastern coastal areas of Taiwan. Master's Thesis, National Taiwan University, Taipei, 119p (in Chinese).

Liu, C.C., Yu, S.B., 1990. Vertical crustal deformations in eastern Taiwan and its tectonic implications. Tectonophysics 183, 111-119.

Lou, Y.H., 1989. ${ }^{14} \mathrm{C}$ Chronological study of the marine terrace in Tatun area, northern Taiwan. Master's Thesis, National Taiwan University, Taipei, 76p.

Peng, T.H., Li, Y.H., Wu, F.T., 1977. Tectonic uplift rates of the Taiwan island since the early Holocene. Memoir, Geological Society of China 2, 57-69.

Shyu, B.H.T., 1999. The sedimentary environment of southern Pingdong Plains since the last glacial. Master's Thesis, National Taiwan University, Taipei, 212p (in Chinese).

Song, S.H., Yang, T., Yeh, Y.S., Tsao, S.J., Lo, H.J., 2000. Is the Tatun volcano group active or extinct? Journal Geological Society of China 43 (3), 521-534.

Sun, S.C., 1982. The Tertiary Basins of offshore Taiwan. Proceedings of second ASCOPT Conference and Exhibition, Manila, Philippines, p. 125.

Sung, S.H., 2001. Sedimentary sequence study of Kaohsiung area since the last glacial Epoch. Master's thesis, National Taiwan University, Taipei, 122p.

Taira, K., 1975. Holocene crustal movements in Taiwan as indicated by radiocarbon dating of marine fossils and drift wood. Tectonophysics 28, T1-T5.

Tan, K., 1933. Flat surfaces of marine erosion around the Daiton volcanic mass. Taiwan Tigaku Kisi 4 (7-49), 57-60 (in Japanese).

Teng, L.S., 1990. Geotectonic evolution of Late Cenozoic arccontinental collision in Taiwan. Tectonophysics 183, 67-76.

Teng, L.S., Lee, C.T., Tsai, Y.B., Hsiao, L.Y., 2000. Slab breakoff as a mechanism for flipping of subduction polarity in Taiwan. Geology 28, 155-158.

Wang, C., Burnett, W.C., 1990. Holocene mean uplift rates across an active plate collision boundary in Taiwan. Science 248 (4952), 204-206.

Yamaguchi, K., 1989. Holocene crustal movement and paleoseismicity of eastern coast of Taiwan. Master's Thesis, Yokohama National University, Yokohama, 111p.

Yu, S.B., Chen, H.Y., Kuo, L.C., 1997. Velocity field of GPS stations in the Taiwan area. Tectonophysics 274, 41-59. 